\title{
7 Who Will Pay for Water? The Vietnamese State's Dilemma of Decentralization of Water Management in the Red River Delta
}

\author{
J.-P. Fontenelle, F. Molle and H. Turral
}

\section{Introduction}

Many state-run large-scale irrigation schemes worldwide have long been financially supported by public funds. Because of stretched public finances and a general trend to hand over the management of irrigation schemes to farmers, an emphasis is often placed on both cost recovery and the financial autonomy of these schemes. Water fees in most countries generally cover only a part of operation and maintenance (O\&M) costs and amount to a small percentage of the agricultural gross product, typically less than $10 \%$. In some other countries, water supply is free and is considered to be a state obligation. However, in situations where irrigation and drainage operations demand the use of pumping devices, operational costs are generally significantly higher, as they include the costs of energy and the maintenance of equipment, and consequently water fees also tend to be higher. This is the case in the Red River delta, where thousands of pumps of all capacities are used in water management.

The Red River delta is also well known for having one of the highest rural population densities of the world. Consequently, agricultural production is extremely inten- sive, cropping intensity is high and the proper management of water is paramount in achieving social welfare and food security. The relationship between the state and the farming population has seen dramatic changes, from colonial times to the recent liberalization, throughout the collectivist period. The question of financing irrigation must therefore be addressed as a particular aspect of a changing political economy, where the taxation system and the roles and responsibilities of the different actors are being redefined. With all these changes, the pumping costs of irrigation and drainage have yet to be covered. This warrants an investigation into how water pricing is conducted in the Red River delta and who eventually pays for what.

The first section of this chapter describes the political changes which induced the technical and institutional evolution of this delta's water control systems, as the organization of the operation and even the technological nature of these systems were influenced by national political choices. The second section describes the management framework and the financial organization of the delta's water control systems. In-depth studies conducted at local level provide a better understanding of the 
present situation. ${ }^{1}$ Water management in the Red River delta appears to be strongly organized by the state into successive nested levels, from the central level of the Ministry of Agriculture to the local level of the cooperatives. This structure has been challenged by the emergence of local pumping stations and water management practices, which have superimposed themselves upon this bureaucratic structure. It is shown that the mismatch between administrative and hydraulic units adds to the complexity of the definition of both the financing and the management of hydraulic operations. The third and last section of this chapter examines the financing of the different operators, the amount and use of the water fees paid by farmers, and questions the process of water management decentralization and 'privatization'2 in the delta. While there is scope for improving downward accountability to farmers, the present system of bulk pricing and nested levels of subsidiarity allows a relatively high rate of cost recovery and a relative financial self-sufficiency.

\section{The Evolution of the Red River Delta Water Control Systems}

With a population of more than 75 million and a total area of $331,700 \mathrm{~km}^{2}$, of which only one-third is covered by plains, Vietnam shows much concern for its food security (Cuc et al.,

\footnotetext{
'This description is based on the results of the 'DELTAS' INCO-DC research project, funded by the European Union (DG XII). In Vietnam, the project was implemented by GRET (Paris) and the Vietnam Agricultural Sciences Institute (Hanoi) between 1998 and 2000. Additional information is sourced from ACIAR (Australia)-funded project 9404 'Integrated management of pumped irrigation systems in the Red River Delta - 1995-1998', carried out with the Vietnam Institute of Water Resources Research. 'The term 'privatization' may be ambiguous and is understood here as the emancipation from the state of groups of users who are able to manage their pumping stations and irrigation schemes independently. However, these undertakings are communal, theoretically non-profit-oriented, and have often been made possible thanks to public funds.
}

1993; Fforde and Sénèque, 1995). Fertile and crowded plains, notably the Mekong and Red River deltas, play a key role as the country's rice bowls. The Red River delta is the smaller and more densely populated of the two deltas (Fig. 7.1). It has a gross area of 1.5 million ha (or $4.5 \%$ of the total area of Vietnam) and a total population of 20 million $(27 \%$ of the total population of Vietnam) (Le Ba Thao, 1997). This represents one of the world's highest rural population densities, with more than 1300 inhabitants $/ \mathrm{km}^{2}$ in some areas. This explains why agricultural intensification, anchored in a strong security against climatic vagaries provided by irrigation, drainage and flood-protection infrastructures, is such a vital issue for the Government of Vietnam.

\section{Water control before collectivization}

High population density is not a new feature of the Red River delta. Population density was already above $400 / \mathrm{km}^{2}$ at the beginning of the 20th century (Dumont, 1935; Gourou, 1936). This delta is an area of ancient human settlement where reclamation by paddy growers has been proved to date back to more than 2000 years (Sakurai, 1989). Early and dense settlements are quite conspicuous, judging from the unfavourable natural conditions faced by the population living in this delta: dangerous river floods and occasional typhoons, as well as droughts, are common during summer monsoons. During dry winter and spring seasons, the main concern is accessing water for irrigated agriculture. To minimize the impact of these constraints, large-scale water control works, such as dykes and canals, were initiated by the imperial state more than eight centuries ago and developed during the 19th century before the arrival of the French (Chassigneux, 1912). Dykes protected the Vietnamese population from floods during the monsoon ${ }^{3}$; during the dry season, canals could receive water

${ }^{3}$ The monsoon in northern Vietnam is characterized by high precipitation and frequent typhoons (Taillard, 1995; Le Ba Thao, 1997). 

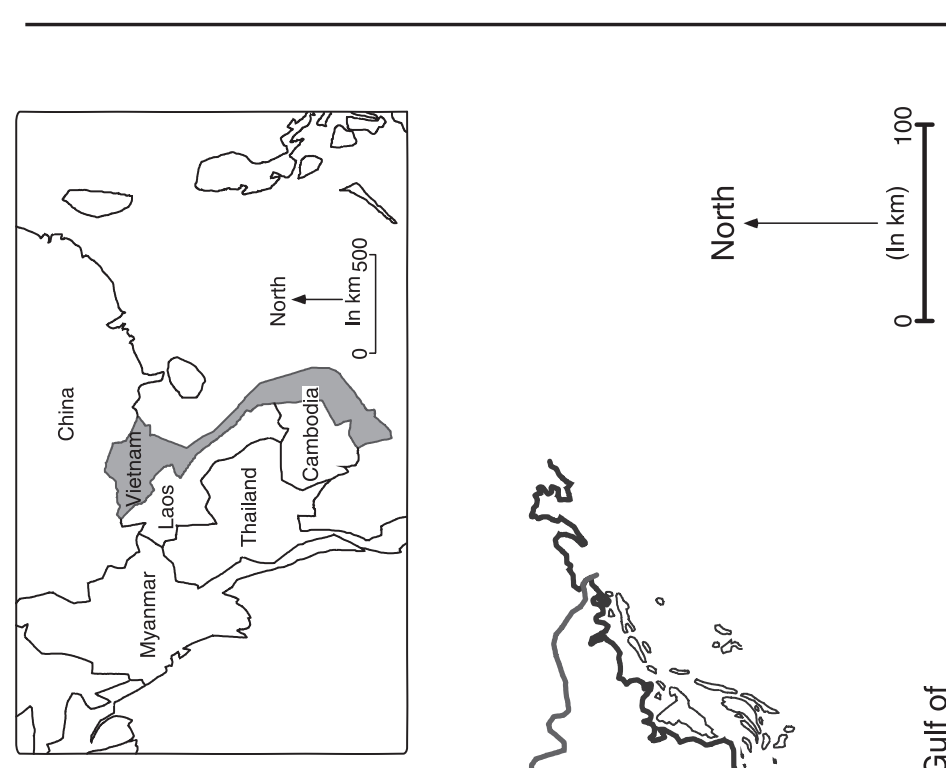

$\oplus$

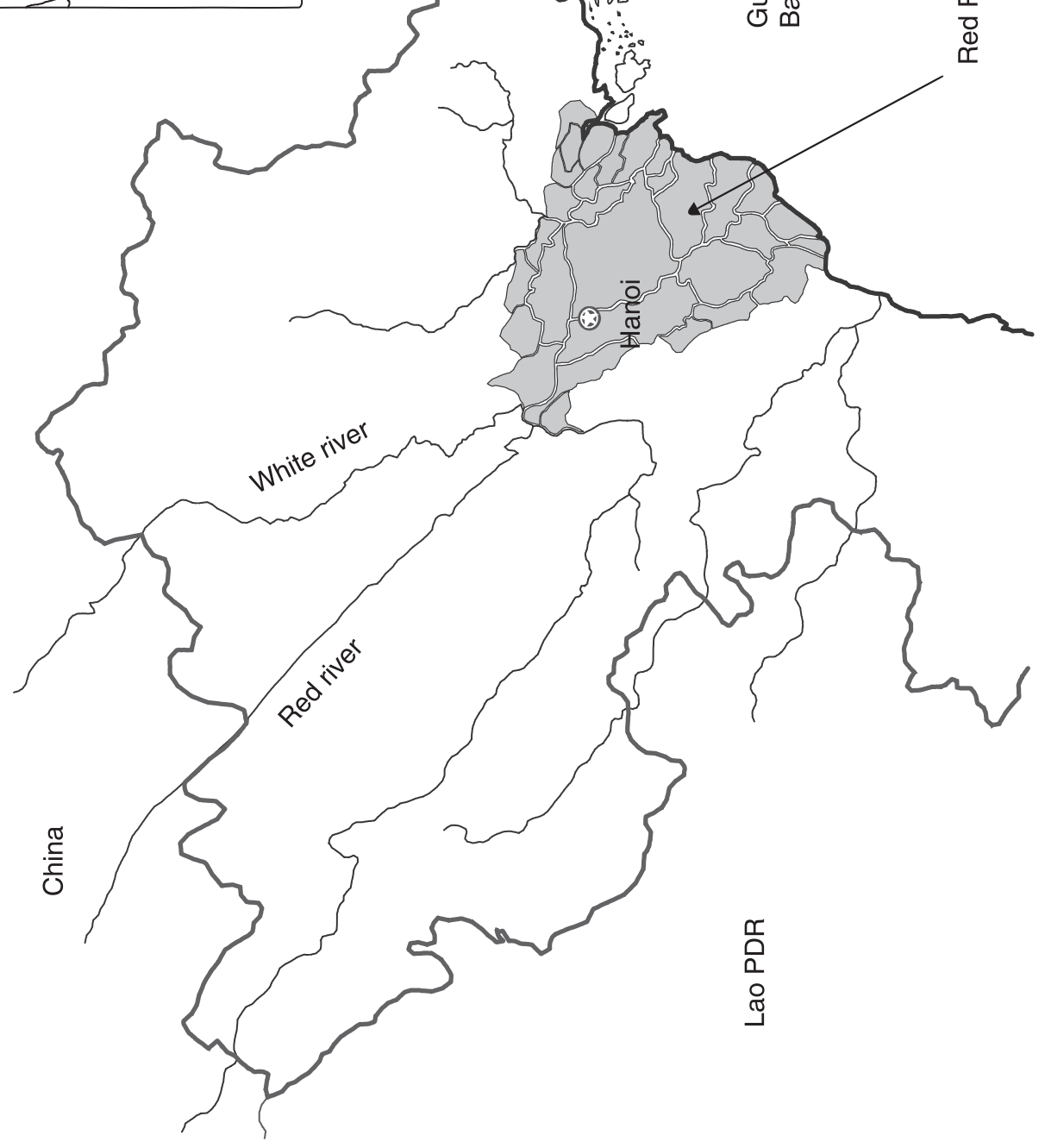

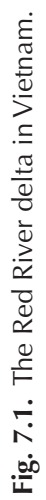


from the river (through sluices in the dykes) and channel it to the lowest paddy fields, gravity allowing. To secure and intensify paddy agriculture, individual irrigation equipments such as water-lifting baskets and tripod scoops were introduced through Chinese influence, which lasted in Vietnam for 1000 years.

The imperial state took responsibility for the construction of dykes, water gates and main canals along river banks by mobilizing local (forced) labour. The responsibility of irrigation was left to the villages (lang xa) (Fontenelle, 1998). During the French colonization, state investment in hydraulic works increased dramatically, with the improvement and completion of the Red River delta system of dykes, gates and the network of main canals. Although the combined action of the central state and farming communities had already gone a long way in developing intensive agriculture in this delta, the farmers' situation remained uncertain due to the occurrence of droughts and floods, as well as the imposition of taxes and the burden of forced labour (Hémery and Brocheux, 1995). Poor drainage within the polders ${ }^{4}$ resulted in continuously saturated conditions and a predisposition to rapid flooding, as the water levels in the river were (and still are) higher than in the surrounding paddy fields during the rainy season. As regards irrigation, low levels in the river made manual water lifting necessary and hindered rice development during the dry season.

\section{The centralized modernization of water control}

The modernization of water control in the Red River delta began in the 1960s under the policy of agricultural collectivization and with the establishment of cooperatives. The modernization of water control was considered a

\footnotetext{
${ }^{4}$ The Red River delta is divided into 30 independent hydraulic units, which are fully dyked and surrounded by arms of the river. These are called polders or casiers, in this chapter.
}

strategic mission, as a necessity towards the collectivization of agriculture. The combined effects of collective mobilization for hydraulic works and the improvement of agricultural conditions were supposed to encourage popular participation in the new cooperative system (Yvon-Tran, 1994).

The state placed great emphasis on mechanized drainage and irrigation. In 1962, 9.8 million man-days of labour were recorded against 2.3 million in 1959. In the Hung Yen province alone, $4000 \mathrm{~km}$ of canals were dug at the end of 1963 . More than $80 \%$ of the direct investments in agriculture by the state were dedicated to the improvement of water control. Large drainage and irrigation schemes were created with a comprehensive network of canals, from the primary to the tertiary level, channels connecting polders to rivers, and large-scale irrigation and drainage pumping stations. Between 1961 and 1965, more than 2500 pumping stations were reportedly ${ }^{5}$ set up in the Red River delta (Vo Nhân Tri, 1967 quoted in Yvon-Tran, 1994). By 1966, $73 \%$ of the cultivated area of the Red River delta was equipped with electrically powered irrigation and drainage pumping stations. Thus water could be extracted and supplied without human labour (Lê Thanh Khoi, 1978). These works, combined with the introduction of improved paddy varieties and chemical fertilizer, led to the further intensification of agriculture and to the double cropping of rice throughout the delta. Beyond the mere modernization of infrastructure, the way in which the Government of Vietnam intended to manage water supply also changed. From a situation where local management at the village level prevailed, water management was transferred to the state, provincial and district water services. Water distribution was organized according to strict irrigation turns among all cooperatives belonging to a single irrigation scheme, and farmers were effectively excluded from the water distribution process (Fontenelle, 1999).

\footnotetext{
${ }^{5}$ These official statistics are subject to caution. However, there is no doubt that the 1960 s witnessed a massive development of large-scale pumping stations.
} 
However, the improvement of food security in the Red River delta did not last long. Between 1960 and 1975, the population resisted and resented the move towards collectivist economy and cooperatives. This, combined with the dysfunctional centralized management, appeared to have compounded an emerging economic crisis (Kerkvliet, 1999). The situation worsened at the end of the 1970s, when the government tried to sustain the collectivist economy through further heavy investments in water control equipment and stronger centralization of production management. Drainage capacities were upgraded through investment in new pumping stations with higher discharge capacity. Most village cooperatives were aggregated into commune cooperatives. Districts became responsible for all production aspects, including the establishment of the crop calendar, choice of rice variety and the management of hydraulic structures. This policy failed dramatically and the very poor living conditions of farmers sometimes degenerated into starvation (Nguyên Duc Truyên, 1993). The food crisis faced in this delta at the end of the 1970s was not the result of a lack of production capacity or funds, since water control infrastructures were well developed by then. This crisis appeared to be due to excessive state intervention, which undermined the capacity of farmers to innovate in, and take control of, production. The crisis was political rather than technical (Tessier and Fontenelle, 2000).

\section{Liberalization reforms and decentralization of water control}

This situation lasted until the beginning of the 1980s, when Vietnamese authorities recognized the failure of the 'great socialist agriculture' and proposed, through the Khoan 100 (Directive 100), a new contract for production with farming households. This contract, in which paddy land was leased to households for a fixed contribution and the surplus of production left to farmers, arose in a context of an economic crisis compounded by farmers' rejection of collectivism (Beresford, 1988; Kerkvliet, 1995). The directive resulted in a boom in agricultural production and encouraged farmers to claim fuller responsibility for agricultural production, including the supply of water. The aspirations of farmers could not be satisfied through the strict rotation of irrigation turns which prevailed in centrally managed schemes. First, individual land management created the need for a specific access to water for each small field leased to farmers, in contrast to the former organization of water supply on large collective plots ${ }^{6}$ (Mai Van Hai, 1999). Second, a strict organization with the establishment of a collectively fixed crop calendar did not allow for the diversification of crops and paddy varieties (Fontenelle and Tessier, 1997). The negative impact of this constraint was reinforced in the case of droughts or power cuts. In order to improve local irrigation conditions, farmers and cooperatives had to free themselves from their dependency on centralized irrigation systems. Farmers deepened existing tertiary canals to store water for a few days after pumping and to gain some flexibility in irrigation at the farm level (Dang The Phong and Fontenelle, 1995). ${ }^{7}$ Cooperatives set up local pumping stations to get direct and autonomous access to water supply (Fontenelle and Tessier, 1997). These pumps were financed by revenues from cooperatives and subsidies from the state. Local pumping stations abstracted water from arroyos $^{8}$ and from the canal networks built by the state in the 1960s. Local irrigation

\footnotetext{
${ }^{6}$ Reality, however, is diverse. In other areas, like Dan Hoai and La Khe polders, the water management groups still do the bulk of in-field water management. Because of the disaggregation of holdings due to land reform, farmers find it too difficult to manage water individually.

${ }^{7}$ This added to significant secondary storage and indrain storage within command areas, which tapped direct supply or return flow from the 'centralized' irrigation systems, which had long been developed. ${ }^{8}$ The term 'arroyo' is used to define the network of natural drainage channels and the lands lying in between that, in most cases, are now bounded by dykes.
} 
schemes thus emerged as fragments of the old centralized irrigation schemes. ${ }^{9}$

The construction of local pumping stations increased during the 1980s taking advantage of further political reforms initiated by the government. In 1984, through Directive 112/ HDBT, the central government decreased its involvement in water management, not only partly devolving management of water control services but also strengthening mechanisms aimed at balancing revenues and costs under strong provincial control. A new actor, the Irrigation and Drainage Management Company (IDMC), was created in each polder. The IDMCs are public companies owned by the state, which were supposed to balance their accounts through the collection of a water fee paid by the cooperatives. They are essentially bulk water suppliers. Furthermore, the Doi Moi reform in 1986, which resulted in the abolition of subsidies and in the liberalization of production activities, the Khoan 10 (Directive 10) in 1988 and the Land Law in 1993, which governs the redistribution of land to farming households, created new conditions for water management and agriculture. Finally, in 1996, the state issued a law on cooperatives aimed at improving their management in a way reminiscent of the 1984 reform of the IDMCs. Cooperatives were no longer considered responsible for production and were supposed to provide service to farmers, for which they could charge a fee. They were still responsible for the collection of water fees paid by the farmers.

Agriculture became more diversified and intensive, as farmers gained the freedom to manage their production individually. Farmers diversified the number of paddy varieties they used, adopted direct seeding techniques, and increased commercial crop production, especially during the winter season (Lê Duc Thinh and Fontenelle, 1998; Bach Trung Hung et al., 1999). These changes

${ }^{9}$ Built along arroyos from which they abstract water, local pumping stations also benefit from the presence of former centralized irrigation canals built on the side of arroyo banks. Therefore, centralized irrigation canals are cut into several reaches, which become primary irrigation canals of the new local irrigation systems. had an impact on water demand, both in terms of overall requirements and frequency of supply (Mai Van Hai, 1999). To meet these requirements the cooperatives increased the number of local pumping stations in order to get more autonomy and flexibility in water supply. These stations now serve approximately half the irrigated area of the Red River delta. High population densities do not seem to have jeopardized food security in the Red River delta as it did in the past, as agriculture now provides more than $300 \mathrm{~kg}$ of paddy per head per year (Dao Thê Tuan, 1998). Agriculture is very intensive and the paddy production of this delta accounts for up to $22 \%$ of all Vietnamese rice production. The people of this delta seem to successfully combine a high population density with intensive agriculture and strong water control measures.

\section{Institutional and Financial Framework of Water Management}

This section focuses on the example of the Bac Hung Hai (BHH) polder. It is the largest polder and the first in which hydraulic modernization was implemented at the end of the 1950s. With an extension of 210,000 ha, 185,000 ha of which are protected by the dyke system, 126,000 ha cultivated and 100,000 ha irrigated, the $\mathrm{BHH}$ polder makes up $13 \%$ of the total area of the delta. It includes 15 districts from four provinces: Hanoi Metropolitan area (1), Bac Ninh province (2), Hung Yen province (6) and Hai Duong province (6) (Fig. 7.2). In 1996, the number of pumping stations in BHH totalled 1022, including 698 local stations.

\section{National and provincial administrative levels}

In 1995, the former Ministry of Water Resources, the Ministry of Agriculture and Food Industries, and the Ministry of Forestry were combined into a new Ministry of Agriculture and Rural Development (MARD). The Department of Water Resources within 


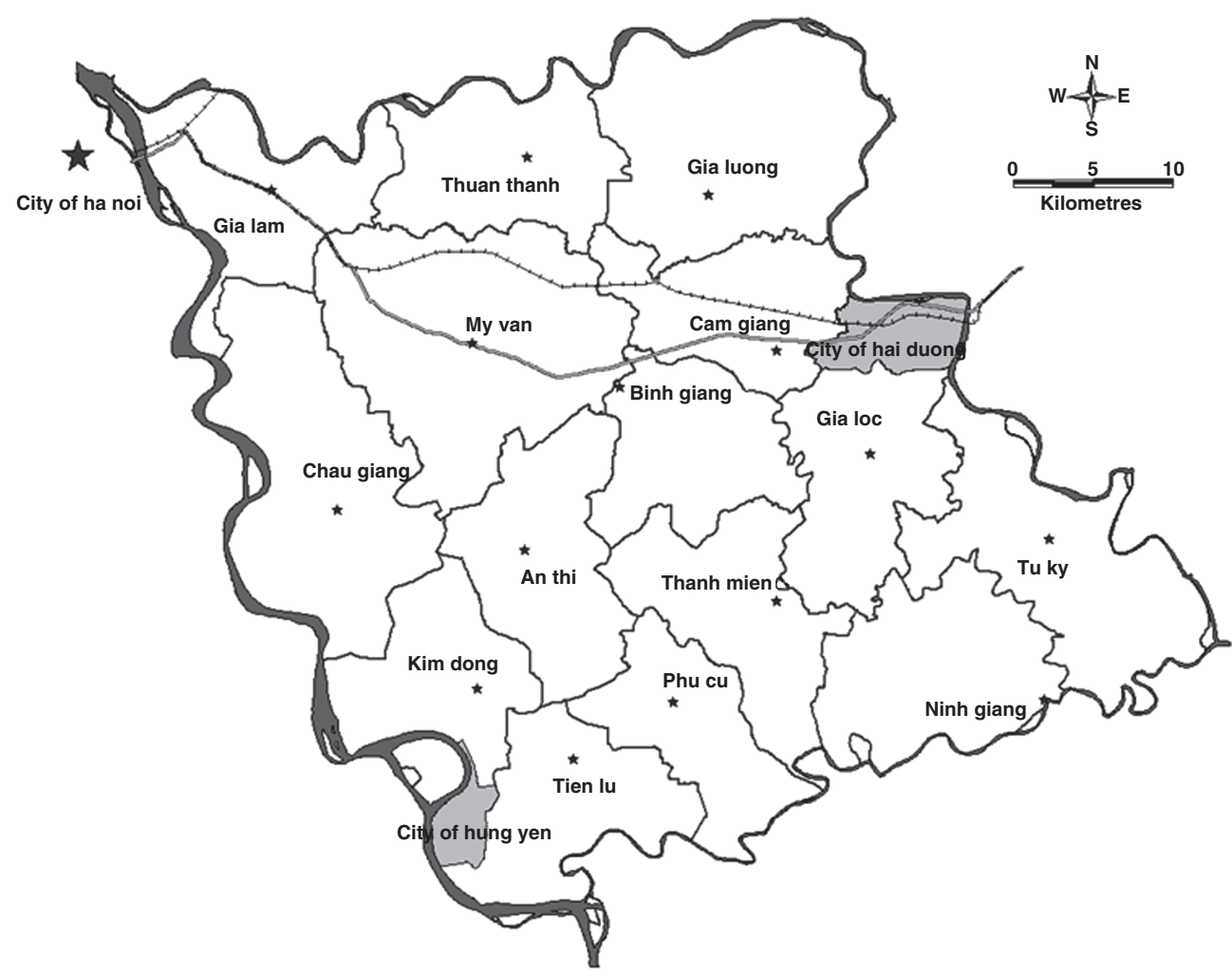

Fig. 7.2. The Bac Hunh Hai polder and administrative boundaries.

this ministry is responsible for the planning, design, construction and funding of major irrigation projects larger than 150 ha. It fixes the national guidelines for the calculation of the water fee according to the type of irrigation (gravity, one or two pumping operations) and drainage (gravity and/or pumping).

The responsibility for managing existing public irrigation and drainage systems, and planning and executing smaller projects is delegated to the province under the leadership of the Provincial People's Committees (PPCs). The PPCs provide policy advice and funds and oversee the work of technical services, set provincial water rates based on national guidelines, allocate subsidies for local water resources projects, and make investments in local infrastructure. The provinces have established Water Resource Services (WRS) to handle these water-related responsibilities. There are ten WRS involved in the water management of the Red River delta, since the delta overlaps ten provinces. WRS are line agencies of the provincial governments. Their duties are similar to those of the central Department of Water Resources in terms of planning, design and construction, but are focused on smaller projects below 150ha.

Additionally, they shoulder the responsibility of calculating water fees paid by farmers, in consultation with PPCs and the party bureaucracy, and oversee the District Enterprises (DEs), which operate irrigation systems within polders. Water fees and their calculation were originally based on a national decree that the government cabinet promulgated in August 1984 (112 HDBT, 1984). Following national policy, the total water fee cannot exceed $8 \%$ of each province's average paddy yield for the last five consecutive seasons, for spring and summer seasons. The fee calculation is based on three subsidiary fees which correspond to rice nursery irrigation, paddy field irrigation and paddy field drainage operating costs. The 
maximum value of the fee for these different services depends on whether water is supplied by gravity, or through one or two pumping operations: the irrigation fee, for example, includes a 'diversion' fee which is paid to the company in all cases (operation of the main system), a pumping fee if such an operation is necessary and a field application fee. The diversity of situations leads to a great complexity in the calculation of the fees. Even though farmers now generally pay in cash, the fee is expressed in kilograms of paddy, and the PPCs determine every year an official rate for $1 \mathrm{~kg}$ of paddy in order to insulate the calculation of the fee from the price fluctuations in the paddy market.

\section{IDMC at the polder level}

IDMCs are provincial state companies established under the WRS to identify and design water resource projects, to construct and repair civil works and to manage irrigation water. Most often, an DMC has responsibility for all existing public irrigation in a primary hydraulic unit (or polder). Several IDMCs can respond to the same WRS when the province encompasses more than one polder. Unlike the Department of Water Resources and WRS, the DMC level is not based on an administrative division but on the polder division. There are 30 DMCs in the delta, managed by 10 provincial WRS (Fig. 7.3). In larger polders, which extend over more than one district, the IDMC is assisted by several subcompanies $^{10}$ (otherwise known as District Enterprises or DEs), one per district concerned. In 1995, 14 DEs were recorded in BHH, the largest polder in the delta. ${ }^{11}$ Each $\mathrm{DMC}$ or DE is structured based on irrigation stations, called cum, each of these being responsible for approx-

\footnotetext{
${ }^{10}$ In the case of $\mathrm{BHH}$, this distinction is important since the DEs are managed by the individual provinces, but the IDMC is managed by a consortium of provinces and the MARD centre: the Director of $\mathrm{BHH}$ does not report to the provinces but to MARD, and is in fact usually in conflict with the provinces over the payment of bulk service charges by the DEs.

${ }^{11}$ The two districts of Bac Ninh province have a joint DE. This is why there are only 14 DEs for 15 districts in the $\mathrm{BHH}$ polder, which overlap with four different provinces (Fig. 7.2).
}

imately 1000ha. Hydraulic cum work with an average of 3-5 cooperatives to manage water, maintain facilities and collect the water fee. Hydraulic cum are responsible for the O\&M of schemes, from the pumping station to the secondary canal..$^{12}$ Overall, the mismatch between hydraulic units (polders, irrigation units) and administrative ones (province, districts, communes) generates a complex set of nested structures. Management practices, financing and accountability will have to be defined at all levels and made compatible.

With the 1997 national Directive 56/CP, IDMCs (and DEs) were transformed into public utilities. They were expected to cover the costs of water diversion, O\&M of irrigation and drainage and depreciation, through the collection of the water fees paid by the farmers. However, IDMCs do not have control over their income and are, in particular, not allowed to raise service fees or keep surplus funds, except for minimal maintenance. In case of climatic hazards, such as typhoons and droughts, state subsidies are supposed to be granted in order to compensate for extra drainage and field application costs, while water fees are reduced in case of paddy losses from flooding. Implementing Directive 56/ CP is the responsibility of each PPC, which adapts the directive to its own situation and issues provincial circulars on this issue.

The DEs are normally responsible for the main pumping infrastructure located at the head of the main canals and for operating the main drainage stations within an irrigation system (usually a large sub-polder). The DEs are nominally district-level organizations, but in practice they may often cover multiple districts within one province. The IDMC operates the main hydraulic infrastructure on the river system and the DEs, which are owned by the individual provinces, pay a bulk water fee to the IDMC. At Bac Hung Hai, the DEs tap water from, and discharge it into, the natural channel and

\footnotetext{
${ }^{12}$ Their formal responsibility ends at the tertiary turnout, which is where the responsibility of the cooperatives' water management groups begins. However, in practice, the cooperatives often control the secondary channels and even sometimes control the operation of the secondary head gates, but this usually brings them into conflict with the company and the cum.
} 


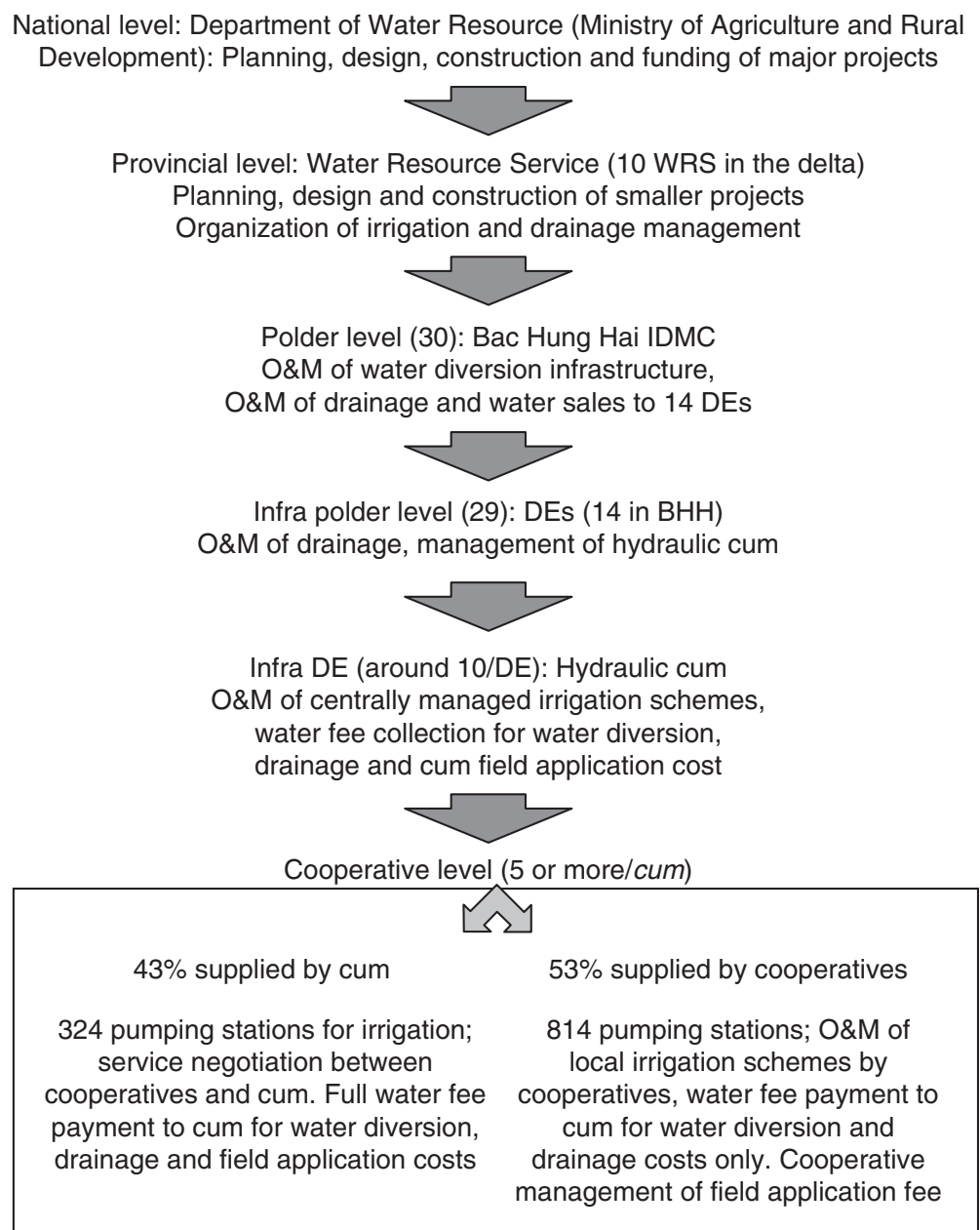

Fig. 7.3. Water management organizational framework in the Bac Hung Hai polder.

main canal network, which is operated by the BHH IDMC. Where the IDMC operates only within a province, payment of bulk water charges is enforced by the Provincial WRS (and the Economic Court) and it has not been a major problem. However, in $\mathrm{BHH}$, the IDMC was jointly owned by four provinces and was then taken under the Ministry's jurisdiction because of financial losses amounting to around \$1.00 million per annum over the period 1994-1998. Underpayment of bulk water charges by DEs has been a significant contributing factor to this situation, and it is still unresolved.

Because of the size of the $\mathrm{BHH}$ polder, BHH IDMC constitutes a special case: before 1998, it was supervised by the Hai Hung pro- vincial WRS. ${ }^{13}$ Nowadays, BHH IDMC is supervised by a System Management Council, constituting representatives from the four provincial WRS concerned, and chaired by the Director of the Department of Water Resources. BHH IDMC is responsible for water diversion and transportation from the river through the dual-purpose central canal network on the whole $\mathrm{BHH}$ polder, and for

\footnotetext{
${ }^{13}$ The Hai Duong and Hung Yen provinces formerly formed the Hai Hung province. The 1997 reform led to the division of several provinces and districts in Vietnam and resulted in the $\mathrm{BHH}$ overlapping with four provinces.
} 
the operation of most tail-end drainage facilities (pumping stations and gravity gates) which discharge outside the dykes of the BHH polder.

Within the BHH polder, the situation of each district depends on the province it belongs to: the DEs from Hung Yen and Hai Duong provinces (which make up $85 \%$ of the BHH-supplied area: Fig. 7.1) pay, based on actual supplied area $(36 \mathrm{~kg} / \mathrm{ha}$ for the spring season and $24 \mathrm{~kg} / \mathrm{ha}$ for the summer season), while DEs of Hanoi and Bac Ninh provinces pay a percentage of BHH IDMC annual expenditures equivalent to the share of area covered by each DE ( $3 \%$ for Hanoi DE and $12 \%$ for Bac Ninh DE). Table 7.1 indicates the breakdown of revenues and expenditures of the IDMC as dictated by the national regulation and its evolution in the Hai Duong province after decentralization measures started to be enacted.

Table 7.1. Annual revenues and expenditures of IDMCs and DEs in the Hai Duong province.

\begin{tabular}{|c|c|c|c|}
\hline & & National regulation & $\begin{array}{l}\text { Hai Duong provincial } \\
\text { regulation }\end{array}$ \\
\hline & & Circular 90/1997/TTLT/TC-NN & Decision 1854/1998/QD-UB \\
\hline \multirow[t]{8}{*}{ Incomes } & \multirow[t]{2}{*}{$\begin{array}{l}\text { Water fee } \\
\text { average level }\end{array}$} & $\begin{array}{l}\text { From } 3 \% \text { to } 8 \% \text { of the } \\
\quad \text { yield Directive } 112 / \mathrm{HDBT} \text { (1984) }\end{array}$ & $\begin{array}{l}\text { From } 1.6 \% \text { to } 5.9 \% \text { of the } \\
\text { yield Decision } 1132 / \\
\text { QD-UB (1993) } \\
\text { Decision 283/QD-UB (1998) }\end{array}$ \\
\hline & & Circular 90/1997/TTLT/TC-NN (1997) & $\begin{array}{l}\text { - when yield decreases } \\
\quad>30 \%\end{array}$ \\
\hline & \multirow[t]{3}{*}{ Public subsidies } & - when yield decreases >30\% & - when income \\
\hline & & $\begin{array}{l}\text { - when income < expenditures } \\
\quad \text { (from national budget) } \\
\text { - when drainage cost }>\end{array}$ & $\begin{array}{l}<\text { expenditures (from } \\
\text { national/provincial } \\
\text { budget) }\end{array}$ \\
\hline & & average ratio $\mathrm{kWh} / \mathrm{ha}$ & $\begin{array}{l}\text { - when drainage cost } \\
\text { > average ratio } \mathrm{kWh} / \mathrm{ha} \\
\text { - permanent subsidy to } \\
\text { decrease water diversion } \\
\text { cost to farmers }\end{array}$ \\
\hline & $\begin{array}{l}\text { Commercial } \\
\text { activities }\end{array}$ & Directive 112/HDBT (1984) & Directive 112/HDBT (1984) \\
\hline & $\begin{array}{l}\text { Gasoline and } \\
\text { electricity }\end{array}$ & $<50 \%$ & Circular 16/DM-XN (1989) \\
\hline & Salaries & $\begin{array}{l}<8 \% \text { of total expenditures } \\
\text { Circular 06/NNPTNT (1998) }\end{array}$ & $\begin{array}{l}<8 \% \text { of total expenditures } \\
\text { Circular 06/NNPTNT } \\
(1998)\end{array}$ \\
\hline \multirow[t]{10}{*}{ Expenditures } & \multirow{2}{*}{$\begin{array}{l}\text { Social and } \\
\text { health } \\
\text { insurance }\end{array}$} & $19 \%$ of salaries & $19 \%$ of salaries \\
\hline & & Directive 112/HDBT (1984) & Directive 112/HDBT (1984) \\
\hline & $\begin{array}{l}\text { Diversion cost } \\
\text { paid to } \\
\text { BHH IDMC }\end{array}$ & Directive 112/HDBT (1984) & $\begin{array}{l}\text { Decision 1132/QD-UB } \\
\text { (1993) }\end{array}$ \\
\hline & $\begin{array}{l}\text { Depreciation of } \\
\text { equipment }\end{array}$ & $\begin{array}{l}\text { Decision 1062TC/QD/CSCT } \\
\text { (1996) }\end{array}$ & $\begin{array}{l}\text { Decision 1062TC/QD/CSCT } \\
\text { (1996) }\end{array}$ \\
\hline & \multirow{4}{*}{$\begin{array}{l}\text { Exceptional } \\
\text { repairs } \\
\text { Ordinary repairs }\end{array}$} & $18-20 \%$ & $16-19 \%$ \\
\hline & & Decision 506TC/DTXD & Circular 06/TL (1990) \\
\hline & & $20-30 \%$ & $14-16 \%$ \\
\hline & & Decision 211/BNN (1988) & Circular 06/TL (1990) \\
\hline & $\begin{array}{l}\text { Water fee } \\
\text { collection }\end{array}$ & $2-3 \%$ & $<3 \%$ \\
\hline & $\begin{array}{c}\text { Management } \\
\text { overheads }\end{array}$ & $5-6 \%$ & $<5 \%$ \\
\hline
\end{tabular}


Regarding public subsidies, the Hai Duong provincial decision No. 283/QD-UB stipulates that altogether $136,000 \mathrm{kWh}$ are annually needed to cover the electricity costs of drainage stations. When drainage needs are higher than this rate, subsidies are granted by the provincial WRS (no longer by the finance ministry) to the IDMC to compensate for the losses. Moreover, a permanent (but small) subsidy is given to the IDMC to decrease the cost of water to farmers. Finally, commercial activities also contribute to the company's income. They include transport fees for boats using the primary canal network, and the maintenance fees for the main works directly carried out by the company. An analysis of the period 1995-1999 showed that, on average, diversion fees paid by DEs amounted to $87 \%$ of the BHH IDMC annual revenue, while subsidies and commercial fees represented only $2 \%$ and $11 \%$, respectively (Nguyen Thi Hong Loan, 2000). Table 7.1 also specifies expenditures in terms of percentage of the revenue. The larger share goes to maintenance work, while salaries plus health-care costs have to remain approximately below $10 \%$.

\section{Cooperatives and farmers}

Cooperatives $^{14}$ are the lowest formal administrative level involved in irrigation and they are collective bodies supposed to represent all the farmers who depend on their agricultural services now mainly concentrated on water and electricity. They are managed by commune officials only, and access to membership (with corresponding rights) is restricted to volunteer farmers (members of the Party or of the Farmers Association). The relationship between cooperatives and DEs, via a hydraulic cum, depends on the existence and the location of local pumping stations. Every year, each cooperative signs a service contract with a cum, which acts on behalf of the district.

\footnotetext{
${ }^{14}$ Cooperatives are established at the commune or village level. In the latter case, the village cooperatives are subsidiaries of the Economic Development Committee of the commune. In any case, cooperatives are closely linked to commune authorities.
}

These contracts are established on a seasonal or annual basis by mutual agreement and signed between each cooperative director and the staff in charge of the cum, or by the DE's director directly. The contract specifies the seasonal or annual water fee to be paid by the cooperative. For the spring season, the area cultivated by the cooperative is indicated and the supplier specified: water can be either provided by the cum or by a local pump of the cooperative itself. For the area to be supplied by the cum, more details are given: these include the kind of crop (rice, rice nursery, food crops or industrial crops), and the kind of irrigation, which is provided (direct gravity irrigation, single or double pumping, 'hand lifted' irrigation). For each type of crop and irrigation, a water fee rate is given in kilograms of paddy per hectare, based on provincial regulations. These rates are multiplied by the area of each type of crop and irrigation, and then aggregated. The sum gives the amount of irrigation fee, including the water diversion costs, to be paid by the cooperative to the cum. For the summer season, an additional fee for drainage is calculated on the basis of the whole area cultivated by the cooperative. The date, place and nature of payment are specified too. Contracts vary according to the watersupply situation of each cooperative, as explained below:

- When there is no local pumping station, cooperatives are responsible for distribution of water and maintenance of irrigation canals, from secondary canals to quaternary canals. They collect a water fee from farmers, which is equivalent to water diversion, drainage and field application costs. Of the fee, $98 \%$ is paid to the hydraulic cum, which supplies them with water, and $2 \%$ is kept by the cooperative for field-level water management.

- When there are local pumping stations built along one of the channels of the polder, cooperatives have to operate and maintain their system from the pumping station down to the quaternary canals. They collect a fee from farmers as explained above but they do 
not pass the total on to the cum. They only pay for water diversion and drainage costs and keep the irrigation fee (adjusted so as to incorporate the cooperatives costs) for themselves.

- When there are local pumping stations that withdraw water from primary (raised) irrigation canals supplied by a pumping station of the cum, cooperatives have to operate and maintain their local systems from the local pumping station to the quaternary canals. The field application fee is increased, since some of it is kept by the cooperative to cover the cost of its own irrigation pumping operations, while the standard fees for diversion, drainage and field application are paid to the cum.

Some cooperatives are fully independent while others still rely on centrally managed pumping stations for a percentage of their irrigated area, ranging from a few hectares to the whole cooperative-irrigated area. Combinations of two of these three cases can also be found within the same coopera- tive, as sub-areas may have different statuses: in such cases, the costs of supplying water to farmers differ but they are averaged in order to come up with a uniform fee per hectare. In the $\mathrm{BHH}$ polder, there are only a few cases of double pumping which are not recorded in DE's statistical data. The official figures indicate that $53 \%$ of the BHH irrigated area is supplied by cooperative stations and $43 \%$ by DEs (Table 7.2 ).

Finally, farmers have to pay part of their annual individual water fee to the cooperative twice a year, after spring and monsoonal rice harvests. The amount they pay reflects the situation of the cooperative regarding irrigation and drainage facilities. They all pay the same amount per unit of area, irrespective of the location of their plots. The water fee is paid together with other levies such as the land tax and several local taxes established by the commune (maintenance of local roads, field surveillance, taxes on houses, gardens and ponds, solidarity tax, etc.). As a result, only a few farmers know the exact amount paid for the irrigation and drainage service (Fontenelle and Tessier, 1997).

Table 7.2. District area supplied by DEs and cooperatives in the spring, 1996.

\begin{tabular}{lccccc}
\hline District & DE (ha) & Cooperative (ha) & Total (ha) & DE (\%) & Cooperative (\%) \\
\hline Gia Lam & 1,665 & 132 & 1,892 & 88 & 7 \\
Thuan Thanh & 4,312 & 1,761 & 6,073 & 71 & 29 \\
Gia Loc & 3,796 & 3,367 & 7,163 & 53 & 47 \\
Chau Giang & 4,934 & 2,129 & 9,675 & 51 & 22 \\
An Thi & 3,238 & 3,651 & 6,889 & 47 & 53 \\
My Van & 5,391 & 6,094 & 11,719 & 46 & 52 \\
Tien Lu & 2,061 & 2,733 & 4,794 & 43 & 57 \\
Thanh Mien & 2,642 & 4,499 & 7,141 & 37 & 63 \\
Kim Dong & 1,547 & 2,749 & 4,296 & 36 & 64 \\
Cam Giang & 1,877 & 3,338 & 5,215 & 36 & 64 \\
Gia Luong & 3,282 & 6,094 & 9,376 & 35 & 65 \\
Phu Cu & 1,671 & 3,244 & 4,915 & 34 & 66 \\
Binh Giang & 1,492 & 4,245 & 5,737 & 26 & 74 \\
Tu Ky & 1,949 & 5,196 & 8,119 & 24 & 64 \\
Ninh Giang & 1,633 & 5,255 & 7,101 & 23 & 74 \\
Total BHH & 41,490 & 54,487 & 100,105 & $43^{b}$ & 53 \\
\hline
\end{tabular}

${ }^{a}$ Cooperatives outside $\mathrm{BHH}$ polder are not taken into account.

${ }^{b}$ The total does not amount to $100 \%$ : a $4 \%$ difference is due to missing data. 


\section{The Intricacies of Water Pricing}

\section{Overlapping rationalities}

The emergence of local pumping-irrigation stations in the Red River delta led to the creation of a dual system where two kinds of irrigation stations, with different technical characteristics, supply fragments of the same original network. In the $\mathrm{BHH}$, there were 814 local stations in 1996 supplying 54,487 ha, and 324 centralized stations supplying 41,490ha. Figure 7.4 provides the example of Van Giang DE, which includes four cum (the average size of local schemes, $67 \mathrm{ha}$, is, therefore, half that of the present (reduced) size of centralized schemes, $128 \mathrm{ha}$ ). Local pumping stations had a higher per-hectare pumping capacity than centralized stations when they were constructed (Table 7.3). Their investment cost per unit area is higher but, on the other hand, they provide several benefits to farmers (Fontenelle and Tessier, 1997; Mai Van Hai, 1999) as listed below:
- Satisfaction of water requirements. Technical surveys conducted on irrigation efficiency at scheme, plot and field levels in the An Binh cooperative, in the Nam Thanh district, showed that crop water requirements were met. This contrasts with the former situation of centrally managed stations where downstream cooperatives could not access water in time (Bousquet et al., 1994; Dang The Phong and Fontenelle, 1995).

- Flexibility/autonomy. Field surveys conducted in 13 communes of the Nam Thanh district have shown that farmers did not want an irrigation interval longer than 7 days (Dang The Phong and Fontenelle, 1997). On local irrigation schemes, there is no delay between the decision to pump and the arrival of water. During the rice season, the full supply by local irrigation units is achieved within a day. Farmers can now complete their land preparation within 2 days, instead of 11, as earlier, which allows them more flexibility in terms of
1962-1976

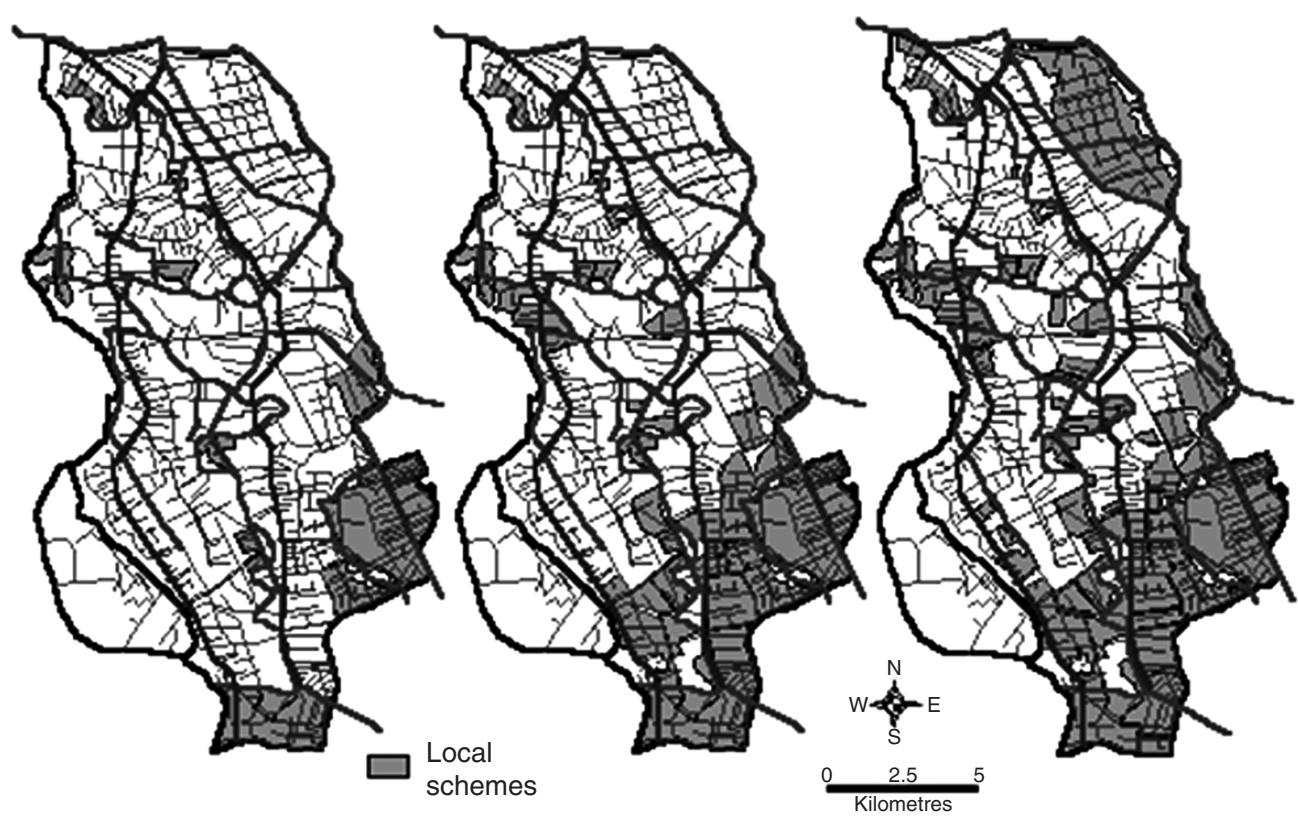

Fig. 7.4. Growth of local irrigation schemes in the Van Giang centralized scheme (Chau Giang district). 
Table 7.3. Comparison of irrigation duration for local and centralized stations.

\begin{tabular}{lccc}
\hline & 24h-average & Land preparation & Rice-season irrigation \\
\cline { 2 - 4 } & $\begin{array}{c}\text { Continuous } \\
\text { flow }\end{array}$ & $\begin{array}{c}\text { Supply of } 100 \mathrm{~mm} \\
\text { (night and day, } 20 \mathrm{~h})\end{array}$ & $\begin{array}{c}\text { Supply of } 30 \mathrm{~mm} \\
\text { (12h maximum per day) }\end{array}$ \\
\hline Local station & $7.0 \mathrm{l} / \mathrm{s} / \mathrm{ha}$ & $40 \mathrm{~h}: 2$ days & $12 \mathrm{h:} 1$ day \\
Centralized station & $1.2 \mathrm{l} / \mathrm{s} / \mathrm{ha}$ & $231 \mathrm{~h}: 11.5$ days & $69 \mathrm{~h}: 6$ days \\
\hline
\end{tabular}

Table 7.4. Average volumes pumped per hectare during spring season 1996. ${ }^{a}$

\begin{tabular}{lccc}
\hline & $\begin{array}{c}\text { Land preparation } \\
\left(\mathrm{m}^{3} / \mathrm{ha}\right)\end{array}$ & $\begin{array}{c}\text { Rice-season irrigation } \\
\left(\mathrm{m}^{3} / \mathrm{ha}\right)\end{array}$ & $\begin{array}{c}\text { Seasonal consumption } \\
\left(\mathrm{m}^{3} / \mathrm{ha}\right)\end{array}$ \\
\hline Local station & 1600 & 2400 & 4000 \\
Centralized station & 3900 & 5900 & 9800 \\
\hline
\end{tabular}

aMonitoring of ten pumping stations in the Nam Thanh district, Hai Duong province. Rainfall during the spring season is $405 \mathrm{~mm}$ on average. For more information on field water balance in the Red River delta see Dang The Phong and Fontenelle, 1995.

cropping patterns and choice of rice variety. The cooperatives' decisions to pump are triggered by the actual water status in paddy fields and not based on a fixed pumping calendar. Managers and users of local schemes are from the same village, or even from the same hamlet. They define their water supplies and rules among themselves, without DE intervention. Localities commonly share irrigation benefits and constraints within their boundaries, as it was the case before the agricultural collectivization of the 1960s (Fontenelle, 1998, 1999).

- Efficiency. The design command area of local schemes is smaller than in centrally managed schemes, below 100 ha instead of 1000 ha or more. ${ }^{15}$ Canals are shorter and less water is wasted compared with centrally managed schemes, which suffer from water losses and illegal water diversions (Bousquet et al., 1994; Fontenelle, 1999). As a result, local stations pump less water per unit of irrigated area than central ones, as

${ }^{15}$ The original area of the centrally managed Van Giang scheme was 14,000 ha. can be seen from Table 7.4. ${ }^{16}$ Differences in water use are due, in part, to the fact that local management is more efficient, but higher per-hectare consumption rates of companies are also due to some illicit arrangements between cooperatives and staff of cum pumping stations. In some instances, staff of pumping stations 'sell' water to cooperatives (which under-report their irrigated areas) in order to increase their income. This increases the total volume delivered per hectare, which puts further pressure on the DE to balance its books, since it cannot revise the charges per unit area.

However, reasons for investing in local pumping stations are not technical only. First, before the end of the 1980s, it was a way to justify and obtain the electrification of a village (thon) or a commune (xa) (Do Hai Dang, 1999). Second, the establishment of a local pumping station in

\footnotetext{
${ }^{16}$ These values are based on two combined approaches. One consisted of the monitoring of date and duration of each pumping. The other consisted of power readings. In both cases they represent actual volumes pumped and do not represent billed amounts.
} 
each village of a commune is sometimes the sign of political competition between influential persons (notables), who all want to have a local station serving their village. Effective continuous flows of $5 \mathrm{l} / \mathrm{s} /$ ha may be technically acceptable but they sometimes reach 10l/s/ha, which are clearly unnecessary as far as paddy cultivation is concerned. Beyond the mere technical question of crop water supply, local water management and investments embody local competition for prestige and power political struggles among commune and village leaders.

\section{Costs to farmers}

To assess the cost of water to farmers, six cooperatives were surveyed in two districts of the BHH. Two were fully responsible for their irrigation and two others partly responsible, while the last two were supplied by the central pumping stations of the company for all their irrigated area (Table 7.5). Results show that when pumping stations are managed by the cooperatives themselves, the calculation of the water fee can be based either on actual costs paid by the cooperatives or on fixed rates chosen by each cooperative. When the water supply to the cooperative depends on central stations the water fee calculation is based on provincial regulations only.

Table 7.6 specifies the amount of water fees paid by farmers and shows significant differences between cooperatives. These can be due to the natural or hydraulic conditions of each cooperative, such as the necessity of double pumping in the Tan Lang commune. But differences should not appear within each type of water supply, since rates are based on the same provincial directives and national decrees. For instance, single pumping fees range from 395 to $473 \mathrm{~kg} / \mathrm{ha} /$ year in the same province of Hai Duong (cf. Table 7.6), which is 'officially' impossible. The highest levy was paid by farmers from the Tan Lang cooperatives, where all irrigated areas are supplied through two consecutive pumping operations. It amounted to $639 \mathrm{~kg}$ of paddy per hectare per year (paddy/ ha/year). The lowest fee was paid by farmers from the Hung Thai cooperative, in which water supply of all types was cheaper than in other surveyed cooperatives. For example, a

Table 7.5. Irrigation type and water fee calculation system for six surveyed cooperatives.

\begin{tabular}{|c|c|c|c|c|c|c|}
\hline $\begin{array}{l}\text { Name of the } \\
\text { cooperative }\end{array}$ & Scale & $\begin{array}{l}\text { Number of } \\
\text { pumping } \\
\text { stations }\end{array}$ & $\begin{array}{l}\% \text { of the area } \\
\text { supplied by } \\
\text { local stations }\end{array}$ & District & Province & $\begin{array}{l}\text { Basis of fee } \\
\text { calculation }\end{array}$ \\
\hline Tan Vinh & $\begin{array}{l}\text { Village } \\
\quad \text { (since 1982) }\end{array}$ & 2 & 100 & Ninh Giang & Hai Duong & $\begin{array}{l}\text { Cooperative } \\
\text { effective } \\
\text { expenditures } \\
\text { (CEE) }\end{array}$ \\
\hline Tan Lang & Commune & 9 & 100 & Gia Luong & Bac Ninh & $\begin{array}{l}\text { Cooperative } \\
\text { fixed rates } \\
\text { (CFR) }\end{array}$ \\
\hline Hung Thai & Commune & 3 & 61 & Ninh Giang & Hai Duong & $\begin{array}{c}\text { Provincial fixed } \\
\text { rates (PFR) }\end{array}$ \\
\hline Dong Tam & Commune & $3(+4+12)^{a}$ & $60^{\mathrm{b}}$ & Ninh Giang & Hai Duong & $\begin{array}{l}\text { CEE for } \\
\text { pumping and } \\
\text { PFR for water } \\
\text { diversion }\end{array}$ \\
\hline Ngo Phan & $\begin{array}{l}\text { Village } \\
\qquad \text { (since 1992) }\end{array}$ & 0 & 0 & Gia Luong & Bac Ninh & $\begin{array}{l}\text { Provincial fixed } \\
\text { rates }\end{array}$ \\
\hline Kim Thao & $\begin{array}{l}\text { Village } \\
\qquad \text { (since 1987) }\end{array}$ & 0 & 0 & Gia Luong & Bac Ninh & $\begin{array}{l}\text { Provincial fixed } \\
\text { rates }\end{array}$ \\
\hline
\end{tabular}

aThere are four local collective diesel pumping stations and 12 individual petrol pumping stations for $28 \%$ of the total cooperative area.

Including the $28 \%$ supplied by diesel and petrol pumps. 
Table 7.6. Water fee paid per type of water supply (in $\mathrm{kg}$ of paddy/ha/year).

\begin{tabular}{|c|c|c|c|c|}
\hline \multirow{3}{*}{$\begin{array}{l}\text { Name of } \\
\text { cooperative }\end{array}$} & \multicolumn{3}{|c|}{ Type of access to water existing within the cooperative } & \multirow[b]{3}{*}{ Remarks } \\
\hline & $\begin{array}{l}\text { Single } \\
\text { pumping }\end{array}$ & $\begin{array}{l}\text { Double pumping } \\
\text { (DE + Local) }\end{array}$ & $\begin{array}{l}\text { Diversion by } \\
\text { gravity }\end{array}$ & \\
\hline & \multicolumn{3}{|c|}{ Total (company + cooperative) } & \\
\hline Tan Vinh & $619(473+146)$ & - & $324(178+146)$ & $\begin{array}{l}\text { Including } 146 \mathrm{~kg} \text { of } \\
\text { extra fee for } \\
\text { maintenance } \\
\text { and new } \\
\text { construction }\end{array}$ \\
\hline Tan Lang & - & 639 & - & \\
\hline Hung Thai & $464(408+56)$ & $345(289+56)^{a}$ & $253(197+56)$ & $\begin{array}{l}\text { Including } 56 \mathrm{~kg} \text { of } \\
\text { extra fee for } \\
\text { maintenance } \\
\text { and new } \\
\text { construction }\end{array}$ \\
\hline Dong Tam & $478(395+83)$ & - & $280(197+83)$ & $\begin{array}{l}\text { Including } 83 \mathrm{~kg} \text { of } \\
\text { extra fee for } \\
\text { maintenance } \\
\text { and new } \\
\text { construction }\end{array}$ \\
\hline Ngo Phan & 475 & 475 & 475 & $\begin{array}{l}\text { Fee averaged for } \\
\text { all, for simplicity } \\
\text { and equity } \\
\text { concerns }\end{array}$ \\
\hline Kim Thao & $586(475+111)$ & - & - & $\begin{array}{l}\text { Including } 111 \mathrm{~kg} \text { of } \\
\text { extra fee for } \\
\text { maintenance } \\
\text { and new } \\
\text { construction }\end{array}$ \\
\hline
\end{tabular}

an fact, in this cooperative there is only one pumping from the DE. The second lift is done manually by farmers.

single pumping operation by a local station costs farmers $464 \mathrm{~kg}$ of paddy $/ \mathrm{ha} / \mathrm{year}$ in the Hung Thai cooperative, which is $28 \%$ cheaper than in the Tan Lang cooperative.

But beyond these differences between cooperatives, another difference is introduced by local extra water fees defined, collected and used by cooperatives to improve the quality of their service (extra costs for local maintenance) and to develop their capacity (capitalizing for new investments in local stations). Extra fees, also referred to as 'exceptional levies', range from 56 to $146 \mathrm{~kg} / \mathrm{ha}$, i.e. between $12 \%$ and $45 \%$ of the total fee.

These differences are a manifestation of their autonomy but they also create a degree of inequity among farmers, who do not benefit from the same production conditions depend- ing on the cooperative they belong to. However, compared with the annual production of paddy (an average of $8 \mathrm{t}$ of paddy in two seasons, plus an additional crop in one-third of the area), water fees appear to be quite small. Even in the Tan Lang cooperative, they do not exceed $8 \%$ of the annual paddy production (not considering the benefit of the winter crop). In most areas of $\mathrm{BHH}$ water can be supplied by a single pumping operation. Therefore, water fees paid by farmers in these cooperatives (including extra fees established by cooperatives) range from $5.8 \%$ to $7.7 \%$ of their annual paddy production, which is reasonably expensive.

The point is that most farmers do not know the details of the calculation of the water fee. This information is withheld by the village chief who is in charge of tax collection on 
behalf of the Commune People's Committee, and downward accountability linkages are weak (Small, 1996). Ambiguity also results from the complexity of the breakdown of the water fee, depending on local conditions and is further strengthened by the fact that land taxes are usually assessed and collected at the same time. Farmers only know how many kilograms of equivalent paddy they have to pay at the end of each rice season, and even if they know the amount of the water fee they are not in a position to ascertain whether the extra fees collected are justified or not and what their exact utilization is (Fontenelle and Tessier, 1997). Sometimes, there is an ambiguity between irrigation services and the provision of electricity to households, which also allows some illicit gains to the cooperatives. ${ }^{17}$ All this lack of clarity is embedded in kinship and patronage relationships and tends to engender mistrust in the villages (Do Hai Dang, 1999). Altogether, the annual taxes paid by farmers amount to $20-25 \%$ of the value of the annual paddy production (Bousquet et al., 1994). They include not only the water fee but also the land tax and several other taxes (house, field watching, cooperative fund, construction of local roads, health, labour insurance, construction, crop damages, 'solidarity tax' for pioneer settlements or solidarity with Cuba, and the police). More than an issue of only taxation, farmers' difficulties are due to the low economic return of paddy production. Production costs (not considering labour and water fees) amount to $25 \%$ of the annual gross value of paddy production. Added to the water fees and other taxes, almost $50 \%$ of farmers' annual gross paddy production value evaporates.

\section{The cooperatives: balanced but non-transparent accounts}

The financial situation of the cooperatives surveyed was analysed using data communicated

\footnotetext{
${ }^{17}$ The electricity for pumping (irrigation) is billed $30 \%$ cheaper than domestic electricity by the company in charge of this service. The cooperatives sometimes apply only the higher tariff to all types of consumption.
}

by the cooperatives themselves, except for the Kim Thao village cooperative, where information was not made available (Table 7.7). On the basis of the available information, it appears that the breakdown of expenditures varies from one cooperative to another.

The number of staff is obviously larger in commune cooperatives than in village cooperatives but it seems that there is no economy of scale as the share of management costs is higher in the former than in the latter. With the available information, it is difficult to interpret correlation between this share and the degree of dependence on the company. The amount paid to the $\mathrm{DE}$ is directly correlated to the percentage of area supplied by the central pumping stations, ranging from $30 \%$ (100\% locally irrigated) to $75 \%$ (100\% centrally irrigated) of total costs. On average, repairs amount to $15 \%$ of total expenditures, and investment in new construction or savings for depreciation of the equipment are not frequent. With the exception of the Tan Lang cooperative, and on the basis of the available values, cooperatives seem to balance their accounts, which are not the cases of IDMCs and DEs, as will be shown later. The main point about these values is that no justification is given for them. Cooperative managers do not present their accounts with more detail than the data provided in this table. Moreover, in three of the surveyed cooperatives no information was provided on the amount of fees collected. Financial transparency is not the rule.

\section{IDMC's finances}

The analysis of annual fee recovery of $\mathrm{BHH}$ IDMC and four DEs showed a cumulative financial deficit. Table 7.8 first illustrates the situation encountered in four DEs, one from each of the provinces overlapping the $\mathrm{BHH}$ polder for four consecutive years. These included Ninh Giang DE from the Hai Duong province, Chau Giang DE from the Hung Yen province, Gia Lam DE from the Hanoi province and Gia Thuan DE from the Bac Ninh province.

The water fee collected annually by each of these four DEs never reached the expected income, but fee recovery from the cooperatives nevertheless exceeded $92 \%$, 
Table 7.7. Annual water management average expenditures and balance (years 1998 and 1999).

\begin{tabular}{|c|c|c|c|c|c|c|c|c|}
\hline $\begin{array}{l}\text { Name of } \\
\text { cooperative }\end{array}$ & $\begin{array}{l}\text { No. } \\
\text { of } \\
\text { staff }\end{array}$ & $\begin{array}{c}\% \\
\text { Management } \\
\text { costs }\end{array}$ & $\begin{array}{c}\% \\
\text { Paid to } \\
\text { DE }\end{array}$ & $\begin{array}{c}\% \\
\text { Electricity }\end{array}$ & $\begin{array}{c}\% \\
\text { Repairs }\end{array}$ & $\begin{array}{c}\% \\
\text { Invested }\end{array}$ & $\begin{array}{c}\% \\
\text { Depreciation }\end{array}$ & $\begin{array}{c}\% \text { (Income - } \\
\text { expenditures)/ } \\
\text { incomes }\end{array}$ \\
\hline Tan Vinh & 9 & 9.7 & 30.1 & 11.5 & 18.7 & 30.0 & 0.0 & +7.3 \\
\hline Tan Lang ${ }^{a}$ & 27 & 9.3 & 29.1 & 44.4 & 17.2 & 0.0 & 0.0 & $-81.4^{b}$ \\
\hline Hung Thai & 17 & 23.0 & 43.6 & 18.8 & 11.9 & 0.0 & 2.7 & +4.0 \\
\hline Dong Tam & 32 & 29.9 & 50.0 & 12.5 & 7.6 & 0.0 & 0.0 & +2.5 \\
\hline Ngo Phan ${ }^{a}$ & 9 & 5.9 & 74.8 & 0.0 & 19.3 & 0.0 & 0.0 & -0.8 \\
\hline
\end{tabular}

${ }^{a}$ Average on 1997, 1998 and 1999.

bElectricity costs are much higher for this cooperative because of double pumping.

Table 7.8. Water fee, incomes and expenditures (DE).

\begin{tabular}{|c|c|c|c|c|c|c|c|}
\hline \multirow[b]{2}{*}{ DE } & \multirow[b]{2}{*}{ Year } & \multicolumn{2}{|c|}{$\begin{array}{c}\text { Water fee } \\
\text { (in billion donga) }\end{array}$} & \multirow{2}{*}{$\begin{array}{c}\text { Incomes } \\
\%\end{array}$} & \multicolumn{2}{|c|}{ Expenditures } & \multirow{2}{*}{$\begin{array}{c}\text { Cost/ } \\
\text { income } \\
\%\end{array}$} \\
\hline & & Due & Collected & & (in billion dong) & (in billion dong) & \\
\hline \multirow{4}{*}{$\begin{array}{l}\text { Ninh Giang } \\
\text { (Hai Duong } \\
\text { province) }\end{array}$} & 1996 & 3.0 & 2.9 & 97 & 3.0 & 3.5 & 117 \\
\hline & 1997 & 2.5 & 2.4 & 96 & 2.9 & 3.6 & 124 \\
\hline & 1998 & 2.7 & 2.4 & 89 & 3.0 & 3.3 & 110 \\
\hline & 1999 & 2.3 & 2.2 & 96 & 2.9 & $?$ & $?$ \\
\hline \multirow{5}{*}{$\begin{array}{c}\text { Chau Giang } \\
\text { (Hung Yen } \\
\text { province) }\end{array}$} & 1995 & 2.4 & 2.4 & 99 & 2.6 & 2.7 & 104 \\
\hline & 1996 & 2.6 & 2.4 & 92 & 2.6 & 3.1 & 119 \\
\hline & 1997 & 2.1 & 2.1 & 98 & 2.2 & 2.6 & 118 \\
\hline & 1998 & 2.8 & 2.7 & 96 & 2.8 & 3.3 & 118 \\
\hline & 1999 & 2.5 & 2.5 & 97 & 2.7 & 3.2 & 119 \\
\hline \multirow{5}{*}{$\begin{array}{l}\text { Gia Lam } \\
\text { (Hanoi } \\
\text { province) }\end{array}$} & 1995 & 2.5 & 2.2 & 88 & 2.5 & 3.0 & 120 \\
\hline & 1996 & 3.2 & 3.0 & 94 & 3.0 & 3.6 & 120 \\
\hline & 1997 & 3.2 & 2.8 & 88 & 2.8 & 4.3 & 154 \\
\hline & 1998 & 3.1 & 2.6 & 84 & 3.3 & 4.3 & 130 \\
\hline & 1999 & 3.9 & 3.2 & 82 & 3.7 & 4.1 & 111 \\
\hline \multirow{5}{*}{$\begin{array}{l}\text { Gia Thuan } \\
\text { (Bac Ninh } \\
\text { province) }\end{array}$} & 1995 & 6.7 & 6.3 & 94 & 7.9 & 6.7 & 85 \\
\hline & 1996 & 8.4 & 7.4 & 88 & 11.0 & 9.5 & 86 \\
\hline & 1997 & 7.1 & 6.5 & 92 & 8.1 & 11.5 & 142 \\
\hline & 1998 & 8.0 & 7.4 & 93 & 9.0 & 11.5 & 128 \\
\hline & 1999 & 8.1 & 7.7 & 95 & 9.1 & 11.0 & 121 \\
\hline Average & 5 years & & & 92 & & & 118 \\
\hline
\end{tabular}

aNote: $\$ 1.00=$ Dong 15,980 .

which is quite remarkable. ${ }^{18}$ However, this is partly achieved though the manipulation of areas and income to be able to report such a recovery rate. The analysis of the annual effective expenditures compared to

${ }^{18}$ The reasons for defaulting are not clear. It is possible that cooperatives which receive poor services decide to withhold part of the fee. Since these figures come from the DEs, it is also possible that these have interest in showing a shortfall. Interestingly, annual effective incomes (fee + subsidies + commercial activities) shows that the situation of the DEs is really unbalanced, with expenditures exceeding incomes by $18 \%$ on average (Table 7.8).

there is a recent move towards establishing contacts between the cum and the cooperatives which are not based on area but on real pumping hours and days. The gains, however, may not reach farmers as they are unaware of the nature of the contracts. 
Table 7.9. Cumulative debt of four DEs (up to 1999, included).

\begin{tabular}{lcccc}
\hline & $\begin{array}{c}\text { Ninh Giang } \\
\text { (in million dong) }\end{array}$ & $\begin{array}{c}\text { Chau Giang } \\
\text { (in million dong) }\end{array}$ & $\begin{array}{c}\text { Gia Lam } \\
\text { (in million dong) }\end{array}$ & $\begin{array}{c}\text { Gia Thuan } \\
\text { (in million dong) }\end{array}$ \\
\hline $\begin{array}{l}\text { Electricity cost } \\
\begin{array}{l}\text { BHH water } \\
\text { diversion fee }\end{array}\end{array}$ & $116(17 \%)$ & $1349(58 \%)$ & $1126(61 \%)$ & $1754(41 \%)$ \\
$\begin{array}{l}\text { Other (repairs, } \\
\text { maintenance, etc.) }\end{array}$ & 444 & 968 & 697 & 1975 \\
$\begin{array}{l}\text { Total } \\
\text { In percentage of } \\
\text { annual income }\end{array}$ & 141 & 0 & 25 & 517 \\
\hline
\end{tabular}

aThese figures account for the totality of the Gia Lam district (communes inside and outside $\mathrm{BHH}$ included).

This situation is due to the incapacity or unwillingness of the provinces to provide subsidies to compensate for the loss, as dictated by the regulation. The shortfall thus corresponds to debts incurred with BHH IDMC and electricity companies, as specified in Table 7.9. On average, the cumulative debt of these companies exceeds $55 \%$ of their annual income, with important differences from one company to another. The status of each company is strongly correlated to the importance of the cumulated electricity debt rather than to the $\mathrm{BHH}$ water diversion fee, which amount is known by each $\mathrm{DE}$ and does not vary much from one year to the next. This does not apply to electricity costs, which depend on annual rainfall and farmers' practices. These differences between incomes and expenditures show that the present regulation does not allow the financial equilibrium of the activities of companies without the provision of subsidies by the national or provincial levels, and the granting of loans by the banks.

A similar analysis was done for $\mathrm{BHH}$ IDMC. Table 7.10 shows that for the 5 years studied the company could not collect the full water diversion fee owed by the 14 DEs. The fact is that DEs do not pay their diversion fee to the BBH IDMC as they should (80\% at the most).

This financial imbalance has a direct impact on BHH IDMC activities. Every year, the company has to submit its activity plan to the authorities. Priority is given to operational activities to the detriment of maintenance and repairs. Financial resources cover priority costs, such as salaries for IDMC staff, electricity and petrol for station operations, costs of water fee recovery and interest on loans. Maintenance and repair activities depend on the annual collected income, on cash flows and loans made with public organizations (banks and public companies). Figures for major repairs show that differences between planned and achieved activities are very large every year (see Table 7.11). It was only in 2 years, 1996 and 1999, that the company could mobilize enough funds to cover the cost of the planned repairs. This is because, in 1996, BHH IDMC got a loan of 3.7 billion dong from

Table 7.10. Comparison between due and collected water diversion fee (IDMC).

\begin{tabular}{lccc}
\hline Year & $\begin{array}{c}\text { Water diversion fee due } \\
\text { (in billion dong) }\end{array}$ & $\begin{array}{c}\text { Water diversion fee collected } \\
\text { (in billion dong) }\end{array}$ & Percentage \\
\hline 1995 & 7.6 & 4.4 & 58 \\
1996 & 8.4 & 6.7 & 80 \\
1997 & 7.4 & 4.3 & 58 \\
1998 & 11.1 & 6.1 & 55 \\
1999 & 9.2 & 6.6 & 72 \\
\hline
\end{tabular}


Table 7.11. Comparison between planned and achieved main repairs (BHH IDMC).

\begin{tabular}{cccc}
\hline Year & $\begin{array}{c}\text { Main repairs planned } \\
\text { (in billion dong) }\end{array}$ & $\begin{array}{c}\text { Main repairs achieved } \\
\text { (in billion dong) }\end{array}$ & Percentage \\
\hline 1995 & 3.7 & 1.6 & 43 \\
1996 & 3.4 & 3.7 & 109 \\
1997 & 3.2 & 1.5 & 47 \\
1998 & 3.8 & 0.9 & 24 \\
1999 & 2.9 & 3.2 & 110 \\
\hline
\end{tabular}

the dredging (public) company and in 1999 it got a subsidy from the Ministry of Agriculture and Rural Development. This shortfall in income weakens the capacity of the IDMC to meet its annual O\&M costs.

\section{Institutional contradictions and difficulties}

From a functional point of view, the relevant unit of an irrigation scheme is the hydraulic unit. But decisions on water management (and, in a large part, on financial issues) are based on administrative decisions and on administrative units. This is a classical problem with irrigation schemes which also applies to the IDMCs and DEs, which are under control of the Water Resource Services of the province. Moreover, some IDMCs, as was the case in the BHH polder, are under the control of more than one province. When water is provided to hydraulic units that span different provinces, the level of fees and subsidies can be different for the same service. Currently, there are four different directives governing the level of the water fee paid by farmers living in the $\mathrm{BHH}$ unit, and policies on subsidies vary from one province to another. This situation leads to inequity in water fees paid by farmers, depending on the province they belong to.

The level of fees is determined by People Committees, under an overall framework fixed by the state. They are based on a percentage of the yield, depending on the kind of water service that is provided. At national and even more at provincial levels, the determination of fees is based more on political considerations than on the economic analysis of water service costs. For example, the level of fees did not follow the huge increase in electricity costs which took place between 1986 and the early 1990s.

The companies have limited control over their income, which depends on the area actually irrigated and drained, and on the level of the fees. Even if they collected $100 \%$ of the fees, Table 7.8 suggests that only half of their deficit would be covered. Officially, provincial subsidies are supposed to cover the differences between income and expenditure. Moreover, the reference for the fees is supposed to be the average yield for the past 5 years. But often, this reference has not been revised since 1984, even if real yields have dramatically increased. In addition, provincial WRS did not add a third irrigation fee for the winter-season crop, even when some irrigation supply was required. Instead, they decided that the cost of the third crop would be covered by subsidies as a political measure to promote intensification of agriculture. This makes DEs reluctant to supply water in winter, which encourages farmers to develop their own pumping schemes. Considering the actual agricultural production (paddy yields and a third winter crop) of farmers, the effective water fee they pay to the companies is lower than the maximum nominal official percentage (5.9\% of yield for Hai Duong).

The main operating costs of companies are electricity and maintenance, along with salaries. The electricity bill depends on the year (and especially on the amount of drainage pumping done) but companies have to meet it even if they jeopardize their annual financial balances, for fear of occasional power cuts. They cannot stop drainage or irrigation when the electricity expenses are above the provisional budget. Most company charges are defined and fixed by the administration. Decrees on water management specify how 
many people have to be employed for each kind of work. Depending on its power, a pumping unit must have a head, a worker and, maybe, a third person. Therefore, the number of persons working for the company is broadly defined by the structure of the scheme. Some officials at the central level say that these norms are too high and that it is not necessary to have so many persons. Salaries, social security contributions, etc., are also fixed by the administration. Even if they wanted to, companies could not significantly reduce the cost of labour. This cost, in all instances, if we trust official statistics, remains under $10 \%$. It is not as high as expected but might reflect employees' very low salaries. Thus, it would be unfair to assimilate these companies to overstaffed agencies commonly found in the irrigation sector, and reducing staff would only yield very limited gains.

In such a situation, companies can only control their expenses by deferring or leaving the maintenance works unpaid. Moreover, for patronage or political reasons, companies may employ more persons than the number fixed by decrees. Most of the maintenance work is done by the companies themselves, or by public enterprises under contract without real competition, which may result in increased costs.

Due to the emergence of local pumping stations, DEs now supply only about $50 \%$ of the area they served originally. Their incomes are based on the area supplied and have therefore significantly declined, but the amounts in electricity bills have also decreased because of the smaller area now serviced. Electricity, however, is only one part of the expenses, and labour or other fixed costs have not decreased, because the number of persons paid by companies remains the same. Moreover, the contract between companies and cooperatives is based on an estimate of the irrigated and drained areas, but companies are not able to accurately determine the effective area. Cooperatives tend to under-report this area as a way to reduce the fee paid to the companies, contributing to widening the gap between DE incomes and costs.

The evolution of the legal status of DEs has constituted a significant step in the restructuring of water management after de-collectivization. Compared with a fully centralized management, it allows a better specification of responsibili- ties. The attempt to oblige DEs and IDMCs to balance their budgets, however, was a failure, despite efforts by DEs to improve fee collection. Defaulting by DEs could, in principle, be dealt with by resorting to provincial economic courts but since the BHH Company was made a national company under MARD such a move could be blocked by the provinces which control the courts. The situation changed in 1999, after riots erupted in Thai Binh in response to taxation perceived as abusive. DEs do not have to present balanced budgets anymore; following decentralization, the provinces became fully responsible for all financial matters relating to the DEs, and the payment of drainage pumping services in 'abnormal' years was devolved to them, rather than being handled by the MARD/central government. With the reduction in central funding and continuing need for capital maintenance and covering community drainage liabilities - the provinces ended up with bigger commitments to subsidy than they had before, driven by central policy but with the responsibility devolved.

\section{Synthesis}

The organizational and financial framework of water control in the Red River delta presents a complex and confusing image. While most countries in Asia have decided to provide irrigation service under high levels of operational subsidy, the Government of Vietnam attempted to recover a significant proportion of operating costs from farmers both before and after economic liberalization in the 1990s. Because of the relatively high cost of service provision arising from extensive pumping for both irrigation and drainage, pressure to recover costs intensified as the rest of the economy liberalized, squeezing the DEs between their service providers (electricity) and an already highly taxed farming population. On the one hand, the liberalization of the economy meant that production costs would have to be covered by the producers themselves and, on the other, the struggle for national food security after more than 30 years of war and scarcity, restrained the state from levying the full cost 
of hydraulic operations from farmers alone. Drainage service benefits the non-agricultural rural and urban population too; the publicgood nature of this service justifies that the state covers part of the expenditures of the IDMCs and DEs and that the farmers and the state (central and provincial) shoulder cost recovery for irrigation and drainage. The Vietnamese State has tried to combine two political goals by striking a balance between rural stability and a service-cost approach to irrigation and drainage.

With the decentralization policy of the 1990s, the organization of the water control in the Red River delta became more complex. From a management point of view, some legislative capacity was transferred to the provincial level. From a technical point of view, the increasing involvement of cooperatives in irrigation and in the development of local pumping stations led to the effective redistribution of responsibilities between the IDMCs, DEs and the cooperatives. The resulting multiplication of circulars and rules for regulation at the central, provincial and communal levels created some heterogeneity and inequity in farm taxation. The water fees paid by farmers may be different from one cooperative to another. The calculation of income and expenditures of the DEs and IDMCs varies according to the province but this heterogeneity stems more from local political decisions than from the variety of hydraulic conditions.

The study also showed the benefits that can be drawn from decentralized and autonomous pumping stations, as opposed to centralized large-scale ones. Agriculture in the Red River delta grew dramatically in intensity and productivity thanks to the development of local pumping stations. The gains in flexibility and responsiveness to water needs came at the cost of what might appear to be excess pump capacity, but these gains are significant enough to encourage the development of local supply, even if the costs per hectare tend to be somewhat higher because of diseconomies of scale. The constraints of collective action are also better accepted by farmers within the limits of villages and communes, which are historically and culturally meaningful. Economically unsound development of local pumping stations may also be encouraged when farmers are able to access public funds and do not pay directly for the investments. The share of these investments paid by the communes varies with time and place. ${ }^{19}$ Public funds can be sourced through the provincial budget, but this is an obscure point in which personal networks of influence ${ }^{20}$ and the influence of the District Party Committees also play a great role.

Water pricing in the Red River delta is primarily geared towards ensuring partial financial stability. The closed nature of the Red River polders indicates that saving in pumping costs translates into financial gains but not into water savings at the macro level (in addition, contracts between cum and companies are generally made on the basis of area and not of volume). In any event, localized water shortages are due to inadequate management and insufficient hydraulic conveyance capacity of secondary canals in the face of uncoordinated pumping operations, rather than to a lack of water resources at the polder level. Even if water is not scarce and water savings largely irrelevant, decreasing abstraction would mean lower energy costs. While local stations have incentives to reduce their own costs, it must be noted that service by the cum is paid based on the area and is independent of the volume effectively supplied. Water charge mechanisms, therefore, have no direct impact on how much water is pumped and on the energy bill (Table 7.12).

The analysis of cooperative financial data suggests that farmers cover between $70 \%$ and $85 \%$ of O\&M costs, not considering depreciation costs which remain dependent on state and/or provincial subsidies. This is, by world standards, a rather substantial contribution to cost recovery. In addition, the expression of the fee in terms of kilograms of paddy has successfully solved the common problem of erosion by inflation, by indexing costs to the price of food.

\footnotetext{
${ }^{19}$ Communes can use different local taxes or state subsidies to support such investments. In the late 1980s, for example, they used subsidies for agricultural input that were made redundant by the liberalization policy.

${ }^{20}$ Such networks may be linked to kinship, the village of origin, batches at the university or in the army, etc.
} 
Table 7.12. Main actors and their strategies.

\begin{tabular}{ll}
\hline Actor & Constraints \\
\hline Farmers & $\begin{array}{c}\text { No control on what the fees } \\
\text { are for. }\end{array}$ \\
& \\
Cooperatives & Need to cover their \\
& electricity and O\&M costs. \\
Direct pressure of farmers & to get water on time. \\
Need to earn income for \\
other needs, services \\
and activities at \\
commune level.
\end{tabular}

Have to ensure irrigation and drainage; do not control revenues; no flexibility for staff hiring. They are far from users and face cum staff's private strategy, opposed to DE's interest.

The fees recovered do not balance their expenditures.

Must cover the costs of drainage service in flood years and claim back subsidies - often paid one year late.

Bac Hung Hai Increasing indebtedness IDMC

\section{Strategies}

Develop local pumping capacity in order to facilitate intensification and diversification of agriculture.

Get water when they need it, no matter what the cost is.

Revolt if tax burden is unbearable.

Partly default on the fee to DE. Use fees for other purposes.

Under-report the supplied area in contracts and negotiate water informally with central pumping stations.

Get local pumping stations to be autonomous in irrigation management, and get access to more funds.

Satisfy the demand of cooperatives in order to complement their low official wages.

Adjust claimed service areas to almost match recovery.

Defer maintenance.

Wait for subsidies for big maintenance works.

Take bank loans to cover operating expenses, particularly for electricity payment.

Defer maintenance.

Wait for government subsidies. Pass the debt on to a central state agency - in this case, the Ministry of Agriculture and Rural Development.
Observations

Fees are area-based. Some village cooperatives introduced fees, based on actual costs: farmers pay for what they get and try to avoid unnecessary supplies.

Investment in local pumps is expensive but their operation is cheaper than for centralized pumps.

Do not have to justify pumping hours to the DE.

Innovation: some cums sign contracts based on effective water consumed by cooperatives.

Have to justify pumping hours to the WRS.

Do not have to present balanced budgets (since the abandonment of the 1997 reforms in 1999).

Recovery at $92 \%$.

Do not have to present balanced budgets. costs, underpayment bulk fees by DEs and failure by provinces to meet their financial obligations. Recovery only $72 \%$. Occasional but irregular subsidies from the government.
Strategies to use the Economic Courts to enforce DE and other provincial payments have faltered. 
Table 7.12. Continued

\begin{tabular}{|c|c|c|c|}
\hline Actor & Constraints & Strategies & Observations \\
\hline Province & $\begin{array}{l}\text { Supposed to pay for the } \\
\text { shortfall of revenue in } \\
\text { case of a special year. } \\
\text { Needs to provide subsi- } \\
\text { dies to DEs since } \\
\text { decentralization is in } \\
\text { process (1999) }\end{array}$ & $\begin{array}{l}\text { WRS/DE subsidizes third crop } \\
\text { on centralized systems but } \\
\text { not for cooperative pumping } \\
\text { stations. } \\
\text { Try to get subsidies from } \\
\text { central government. Provide } \\
\text { provincial directives to adjust } \\
\text { national decrees to provincial } \\
\text { conditions and policy. }\end{array}$ & $\begin{array}{l}\text { Responsibility of } \\
\text { each province } \\
\text { lessened because } \\
\text { four provinces are } \\
\text { represented on the } \\
\text { BHH IDMC board. }\end{array}$ \\
\hline State & $\begin{array}{l}\text { Has control over BHH } \\
\text { IDMC through the } \\
\text { Ministry of Agriculture } \\
\text { and Rural Development } \\
\text { and is requested by } \\
\text { provinces to help for } \\
\text { investments and major } \\
\text { works. } \\
\text { Has to adapt its policy to } \\
\text { ecent changes which were } \\
\text { not planned (emergence } \\
\text { of local pumping stations) } \\
\text { and decentralization to the } \\
\text { provinces. The present } \\
\text { institutional framework } \\
\text { does not fit the present } \\
\text { organization of irrigation. } \\
\text { To get funds from interna- } \\
\text { tional donors (which } \\
\text { means to include some } \\
\text { transfer measures in } \\
\text { water policy); to reform } \\
\text { without giving up strong } \\
\text { administrative control of } \\
\text { farmers. }\end{array}$ & $\begin{array}{l}\text { Do not fully compensate for } \\
\text { financial deficit as a way to } \\
\text { maintain pressure on IDMC } \\
\text { and to conserve its financial } \\
\text { resources. } \\
\text { Do not ask for full recovery in } \\
\text { order to keep a balance } \\
\text { between financial con } \\
\text { straints and social peace. }\end{array}$ & $\begin{array}{l}\text { Fear of countryside } \\
\text { social unrest, as } \\
\text { expressed in the } \\
\text { Thai Binh riots of } \\
\text { 1999. }\end{array}$ \\
\hline
\end{tabular}

Part of the fees is dedicated to the satisfaction of their irrigation needs but the opacity of the management of cooperatives does not allow farmers to estimate the adequacy of their payment with regard to the real costs incurred by cooperatives. This opacity is also allowed by the wide diversity of situations regarding water control (irrigation and drainage at field level may be achieved by gravity or with a complex mix of pumping operations) combined with an institutional diversity (the operations can be ensured by the cooperative and/or the company), which makes the calculation of fees very complex. Moreover, it also points to the fact that cooperative managers are generally administra- tive cadres, sometimes pursuing agendas beyond the scope of irrigation itself, as do company officials and district and provincial politicians. Local political practices are inclined to heavy investments in hydraulic equipment and in other infrastructures, such as roads, which can create an unbearable burden to the farmers: the 1999 riots in the Thai Binh province were motivated by mismanagement of the fees, which were raised and used for building roads and for paying bribes or extra salaries to the local authorities instead of for irrigation services.

One could argue that the water fees paid by farmers are still low in the Red River delta, but that the official water fees, which 
are often increased by many 'unofficial' subsidiary fees and taxes managed with little transparency, do not encourage farmers to contribute to the cost recovery of irrigation and drainage activities and generates mistrust. Water charges are not a goal in themselves, and are not something new in a context where farmers have paid taxes to the central state for centuries, but they should be linked to a clear definition of responsibilities and to management accountability. Interestingly, new contractual agreements signed between some cum and cooperatives aim to base payments on the cooperatives' effective water consumption, and tend to reinforce downward accountability.

The same opacity prevails regarding the management of IDMCs and DEs. The companies lack the incentives to present balanced budgets, since provincial or state subsidies will finally cover the deficit, and may be inclined to favour the satisfaction of their internal needs to the detriment of the quality of service. The permanent debt regarding the water diversion fee due to the IDMC and the electricity cost can be seen as a deliberate management policy: an upward transfer of the financial burden directly to the province, for the electricity, and to the state via BHH IDMC for the water diversion and main repairs. ${ }^{21}$ This informal strategy was confirmed during interviews conducted with company officials during our research. At the same time, the companies also transfer part of their costs downward to the cooperatives by eliciting unofficial payments to field staff aimed at ensuring diligence and timely service. For the state, letting the debt grow might be a better strategy than purely making up for the financial shortfall with subsidies, since it allows maintaining a degree of pressure on provinces and districts by making manifest their lack of financial rigour (regardless of whether they are responsible for this or not). In addition, the state has now shifted some of its financial burden on to the provinces by making them responsible for covering possible extra costs in abnormal years.

${ }^{21}$ At least for Bac Hung Hai and Bac Nam Ha polders.
All this shows that both within the cooperative level and between the cooperative and state companies, issues of water pricing are embedded within social networks based on kinship and political connections. Financial interdependence must therefore be seen not only as a mere contractual relationship, whereby financial flows are defined by reciprocal accountability and managerial rationality, but also as a part of the wider social and political web marked by shifting individual strategies, asymmetries of information and of bargaining power, and varying access to higher political strata. Just like in the case of cost recovery in the National Irrigation Administration of the Philippines, the model of contractual and financial autonomy of irrigation agencies proves to be oversimplistic in that it largely overlooks local politics (Oorthuizen, 2003).

Despite these qualifications, the crucial point is to determine whether the financial imbalance is the result of poor management and significant improvements are possible, or whether real constraints such as rising electricity bills, straightjacketing official regulation on fees and shrinking service areas do not allow companies to fare much better. Reality borrows from both ends, although our analysis tends to lean towards the latter. On the one hand, the overall financing of irrigation and drainage gives way to complex financial flows between nested levels of power and responsibility (farmers/cooperatives/companies and provinces/state), and the lack of transparency suggests that the economic efficiency of the service provision decreases due to financial losses at several levels. On the other, the debts of companies can be seen as implicit state subsidies made necessary by the political decision to keep water charges under a certain level. Since the overall taxation of households was shown to be quite high, this concern might be a practical recognition that surplus extraction by the state cannot be increased (the agricultural tax was reduced in 1993 in order to reduce the tax burden (Small, 1996), before being cancelled in 2001), and an indication that farmers' contributions might, after all, exceed what they get from the state in return, a point that 
needs further investigation. The apparent low percentage of companies' income spent on staff salaries (around 10\%) indicates that administrative reforms might yield fewer gains than expected, although the extra payments made by farmers also show that these real costs might be higher than indicated.

In other words, the shortfall in the budgets of cooperatives, DEs and the BHH IDMC reflects both the non-optimal management of these organizations and the insufficient levies imposed on users, and the degree of defaulting that these organizations allow themselves is also a reflection of their perception of how much the state may be willing to pay, to avoid the transaction and political costs of engaging in more drastic or coercive reforms. It is also a measure of the 'distance' between the centre and decentralized administrative units, and of how upper bureaucratic layers fail to exert full control upon lower ones. From another point of view, it defines the trade-off between social considerations (constitutive of the Vietnamese Party's legitimacy) and macroeconomic constraints. Any institutional reform must question the distribution and share of responsibility in decision making, and introduce higher transparency in financing. This, of course, is an issue that cannot be restricted to the water sector and pertains to the wider question of political change in Vietnam.

\section{References}

Bach Trung Hung, Tran Ngoc Hân, Nguyen Van Dung and Le Quéré, E. (1999) Evolution de la riziculture de 1991 à 1995. In: Agriculture Familiale et Gestion des Ressources du Milieu dans le Basin du Fleuve Rouge. INSA, GRET, PFR, Maison d'Edition de l'Agriculture, Hanoi, pp. 147-159.

Beresford, M. (1988) Vietnam: Politics, Economics and Society. Pinter, London, p. 242.

Bousquet, M. in collaboration with the team 'Gestion Sociale de l'Eau du Programme Fleuve Rouge' (1994) La Gestion de l'eau à An Binh: Evolution Historique, Technique et Sociale. GRET, Paris and CNEARC, Montpellier, France.

Chassigneux, E. (1912) L'irrigation dans le Delta du Tonkin. Revue de Géographie Annuelle, tome IV, fascicule I, Paris.

Cuc, Le Trong, Gillogly, K. and Rambo, A.T. (eds) (1993) Too Many People, Too Little Land: The Human Ecology of a Wet-Rice-Growing Village in the Red River Delta of Viet Nam. Program on Environment. Occasional Paper No.15. East-West Center, Honolulu.

Dang The Phong and Fontenelle, J.-P. (1995) Bilan hydrique à l'échelle de la parcelle et de la maille, et pratiques individuelles d'irrigation pour la campagne de printemps 1993, dans le delta du Fleuve Rouge, au Vietnam. In: L'agriculture du Delta du Fleuve Rouge à l'heure des Réformes. INSA, PFR, Maison d'Edition de l'Agriculture, Hanoi, pp. 255-284.

Dang The Phong and Fontenelle, J.-P. (1997) Le passage à la gestion locale de l'irrigation dans le delta du fleuve Rouge: cas du district de Nam Thanh. In: Spécial Vietnam, Numéro commun Cahiers Agricultures 15, 93-99.

Dao Thê Tuan (1998) La transition agraire au Vietnam comme changement d'institutions. In: Développement et Transition vers l'économie de Marché. Actualité Scientifique, Universités Francophones, AUPELF-UREF, Montreal, Canada, pp. 457-471.

Do Hai Dang (1999) Action collective et jeux de pouvoir dans la gestion locale de l'irrigation. Le cas du delta du Fleuve Rouge (Vietnam). Masters thesis, Fondation Universitaire Luxembourgeoise, Arlon, Belgium.

Dumont, R. (1935) La culture du riz dans le delta du Tonkin. Sociétés d'édition géographiques, maritimes et coloniales, Paris.

Fforde, A. and Sénèque, S. (1995) The economy and the countryside: The relevance of rural development policies. In: Kerkvliet, B.J. and Porter, D.J. (eds) Vietnam's Rural Transformation. Westview Press, Boulder, Colorado, pp. 97-138.

Fontenelle, J.-P. (1998) L'eau de l'Etat et l'eau des villages: I'exemple de I'hydraulique du delta du Fleuve Rouge. In: Sociétés Rurales et Environnement. Karthala, GRET et Regards, Paris, pp. 75-95.

Fontenelle, J.-P. (1999) The Response of Farmers to Political Change: Decentralization of Irrigation in the Red River Delta, Vietnam. Liquid Gold Series, Paper 5. Agricultural University, ILRI, Wageningen, The Netherlands.

Fontenelle, J.-P. and Tessier, O. (1997) L'appropriation paysanne de I'hydraulique agricole du delta du Fleuve Rouge: processus et limites. Autrepart 3. Editions de I'Aube, ORSTOM, Paris, pp. 25-43. 
Gourou, P. (1936) Les Paysans du Delta Tonkinois. Publications de l'Ecole Française d'Extrême Orient, Les Editions d'art et d'histoire, Paris.

Hémery, D. and Brocheux, P. (1995) La colonisation Ambigüe 1858-1954. La Découverte, Paris.

Kerkvliet, B.J.T. (1995) Rural society and state relations. In: Kerkvliet, B.J.T. and Porter, D.J. (eds) Vietnam's Rural Transformation. ISEAS, Westview Press, Boulder, Colorado, pp. 65-96.

Kerkvliet, B.J.T. (1999) Accelerating cooperatives in rural Vietnam, 1955-1961. In: Dahm, B. and Houden, V.J. (eds) Vietnamese Villages in Transition. Department of South-east Asian Studies, Passau University, Passau, Germany, pp. 53-88.

Le Ba Thao (1997) Vietnam the Country and Its Geographical Regions. The Gioi Publishers, Hanoi.

Lê Duc Thinh and Fontenelle, J.-P. (1998) Systèmes de cultures, stratégies paysannes et environnement institutionnel dans le delta du Fleuve Rouge. In: Proceedings of the 15th International Symposium: Rural Livelihoods, Empowerment and the Environment. Going beyond the Farm Boundary. Association for Farming Systems Research-Extension, Pretoria, South Africa, pp. 754-762.

Lê Thanh Khoi (1978) Socialisme et Développement au Viêt-nam. Puf, Paris.

Mai Van Hai (1999) Participation des agriculteurs aux travaux d'irrigation depuis le contrat 10. In: Agriculture Familiale et Gestion des Ressources du Milieu dans le Basin du Fleuve Rouge. INSA, GRET, PFR, Maison d'Edition de l'Agriculture, Hanoi, pp. 25-38.

Nguyên Duc Truyên (1993) Les Effets de la Politique Economique Vietnamienne sur les modes de vie Paysans dans la Région du delta du Fleuve Rouge. Mémoire de DEA, EHESS, Paris.

Nguyen Thi Hong Loan (2000) Politiques de Gestion Financière des CEOH - Situation Actuelle des Activités Financières des Compagnies du Système Hydraulique de Bac Hung Hai. Deltas INCO-DC project, VASI, Hanoi.

Oorthuizen, J. (2003) Water, Works, and Wages: The Everyday Politics of Irrigation Management Reform in the Philippines. Wageningen University Water Resources Series. Orient Longman, Hyderabad, India.

Sakurai, Y. (1989) Land, Water, Rice, and Men in Early Viêt-Nam: Agrarian Adaptation and Socio-Political Organization. In: Taylor, K.W. (ed.) The Center for South-east Asian Studies, Kyoto University, Kyoto, Japan.

Small, L.E. (1996) Irrigation operation and maintenance in Vietnam under economic restructuring. Irrigation and Drainage Systems 10(2), 245-262.

Taillard, C. (1995) Le Viêt-nam, émergence d'un nouveau dragon. In: Antheaume, B., Bonnemaison, J., Bruneau, M. and Taillard, C. (eds) Asie du Sud-Est Océanie. Géographie Universelle, R. Brunet Dir., Belin-Reclus, Paris, pp. 188-211.

Tessier, O. and Fontenelle, J.-P. (2000) Pression démographique et contraintes politiques: La paysannerie du delta du Fleuve Rouge dans la tourmente du XXème siècle. In: Gubry, P. (ed.) Population et Développement au Viêt-nam. Karthala, Paris, pp. 495-527.

Yvon-Tran, F. (1994) Une résistible collectivisation; L'agriculture au nord Vietnam: 1954-1988, PhD thesis. Université de Paris VII, Paris. 